(C) 2007 IEEE. Reprinted, with permission, from Yuedong Zhan and Youguang Guo , A PEMFC/Battery Hybrid UPS System for Backup and Emergency Power Applications, Power Electronics and Drive Systems, 2007. PEDS '07. 7th International Conference on, and November 2007. This material is posted here with permission of the IEEE. Such permission of the IEEE does not in any way imply IEEE endorsement of any of the University of Technology, Sydney's products or services. Internal or personal use of this material is permitted. However, permission to reprint/republish this material for advertising or promotional purposes or for creating new collective works for resale or redistribution must be obtained from the IEEE by writing to pubs-permissions@ieee.org. By choosing to view this document, you agree to all provisions of the copyright laws protecting it 


\title{
A PEMFC/Battery Hybrid UPS System for Backup and Emergency Power Applications
}

\author{
Yuedong Zhan*,**, Jianguo Zhu**, Youguang Guo**, and Hua Wang* \\ * Department of Automation, Kunming University of Science and Technology, Kunming, 650093, China \\ ** Faculty of Engineering, University of Technology, Sydney (UTS), NSW 2007, Australia
}

\begin{abstract}
This paper presents the development of a proton exchange membrane fuel cell (PEMFC) and battery hybrid uninterruptible power system (UPS) for backup and emergency power applications. A sixty-cell PEMFC stack is employed as the main power source at normal load and a 3cell lead-acid battery is employed as the auxiliary power of the UPS at overload or during the PEMFC startup. The PEMFC consists of two valves for the hydrogen input and output respectively, a mass flow controller to adjust the hydrogen mass flow, and a pressure sensor to control the hydrogen pressure, and their control units for the management of the whole system. The design procedures of the UPS hybrid system are discussed. Experimental setups are presented and the experimental results verify the performances of the PEMFC/battery hybrid power source and the UPS system under the condition of computer load. The developed UPS system proves to be a cost-effective solution for backup and emergency power applications.
\end{abstract}

Index Terms--Backup and emergency power applications, fuel cell/battery hybrid power source, proton exchange membrane fuel cell (PEMFC), uninterruptible power supply (UPS).

\section{INTRODUCTION}

To provide backup and emergency power for critical loads, such as computers, medical and life support systems, communication systems, and industrial controllers, in case of power failures, the uninterruptible power supply (UPS) systems have played an important role. A high performance UPS system should have a clean output voltage with low total harmonic distortion (THD) for the unbalanced linear and nonlinear loads, high efficiency, great reliability and fast transient response for sudden load changes [1]. Besides these, an ideal UPS should have the following features: regulated sinusoidal output voltage with low THD and independent from the changes in the input voltage or in the load, online operation that means zero switching time from normal to backup mode and vice versa, low THD sinusoidal input current and unity power factor, low electromagnetic interference (EMI) and acoustic noise, electric isolation, low maintenance, and low cost, weight, and size. Therefore, UPS systems that can keep the information and data from being destroyed have become very popular. Particularly, with the popularization of personal computers and Internet, low capacity UPS

This work was partly supported by the UTS Pro Vice Chancellor R\&D Seed Fund. products will take an increscent part in the industrial and domestic markets.

As to the backup and emergency power applications, conventional approaches using batteries have problems with life, pollution, maintenance and weight. Similarly, diesel generators have problems with startup, maintenance, noise and emissions. Although the metal hydride fuel cells offer a fundamentally new approach to fuel cells that results in a practical, low cost technology with unique performance advantages, including intrinsic energy storage, instant start capability, good lowtemperature performance, and fuel "hot swap" capabilities [2], the liquid-fed direct methanol fuel cells (DMFC) and proton exchange membrane fuel cells (PEMFC) using hydrogen as fuel are still considered as the well-developed and the most promising fuel cell technologies [3]. In this paper, a PEMFC stack is selected because it features higher power densities than the DMFC; the latter has additional problems due to crossover and slow anode electro-catalysis of methanol.

Compared with the fuel cells, lead-acid rechargeable batteries have a rapid transient response without any warm up or start up time, and their specific power capability is also much higher than that of fuel cells [4]. Combining the fuel cells and small capacity battery, the PEMFC/battery hybrid UPS system make the best use of the advantages of each individual device, and may meet the requirements for the above mentioned applications regarding both high power and high energy density.

This paper mainly presents the experimental study of an actively and passively controlled PEMFC/battery hybrid UPS system for backup and emergency power applications. It addresses the design of the UPS system with PEMFC/battery hybrid power source, and the experimental results obtained during the normal and backup modes of the UPS system, as well as the currentvoltage and power performances of the PEMFC stack. Additionally, the dynamic characteristics are tested as a function of the PEMFC and battery load sharing in the backup hybrid power source. The PEMFC is applied as the main power source for the UPS system, the battery is connected as an auxiliary power source, and the characteristics of the change of current and power depending on the load in the PEMFC/battery hybrid power source are analyzed. The development of this PEMFC/battery hybrid power system would provide a sound basis for further study on portable backup and emergency power supply applications. 


\section{SYSTEM SETUP}

Fig. 1 illustrates schematically the structure of a singlephase high frequency $300 \mathrm{~W}$ UPS with a backup $300 \mathrm{~W}$ PEMFC generating unit and battery, which is composed of $\mathrm{AC} / \mathrm{DC}$ rectifier, $\mathrm{AC} / \mathrm{DC}$ charger, $\mathrm{DC} / \mathrm{AC}$ inverter and DC/DC converter and their data acquisition and control devices. The UPS system supplies the load with the required and uninterruptible $\mathrm{AC}$ power. The PEMFC stack operates on hydrogen and air. Because of the sudden changes of the UPS load and the slow start-up of the PEMFC stack, which may take a few seconds before its output voltage reaches the rated voltage, a small capacity battery or ultra-capacitor is required for UPS applications.

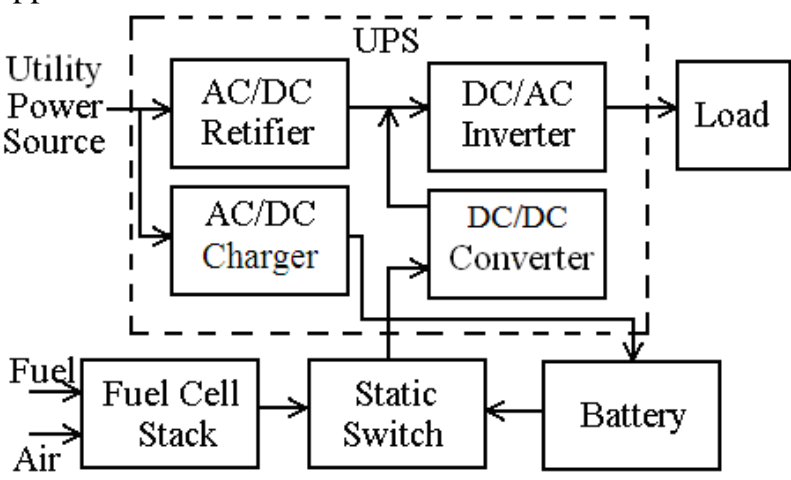

Fig. 1. UPS system with backup PEMFC and battery

\section{A. PEMFC Stack}

The PEMFC stack is a self-humidified, air-breathing, 60 -cell stack with an overall size of $22.0 \mathrm{~cm} \mathrm{x} 10.5 \mathrm{~cm} \mathrm{x}$ $7.0 \mathrm{~cm}$, as shown in Fig. 2. In the presented PEMFC system, there is an option to humidify the hydrogen gas and to use oxygen instead of air. To improve the cooling of the stack, three fans are used. The stack has a maximum operating temperature of $65{ }^{\circ} \mathrm{C}$ and an operating pressure of 4.55-5.5 psi for hydrogen.

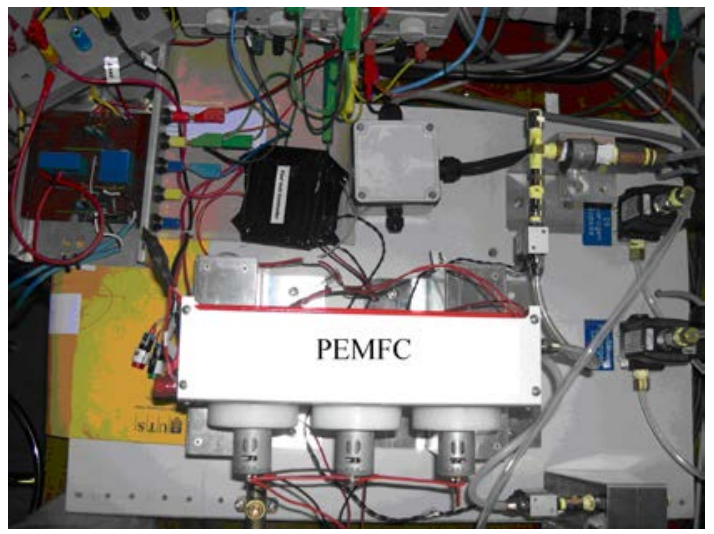

Fig. 2. Photo of the $300 \mathrm{~W}$ PEMFC stack

To use the PEMFC stack as the backup and emergency power source, there is one polarization curve given in the operator's manual [5] that will be used in later analysis of the proposed model. Fig. 3 indicates the current-voltage and power characteristics of the PEMFC stack.
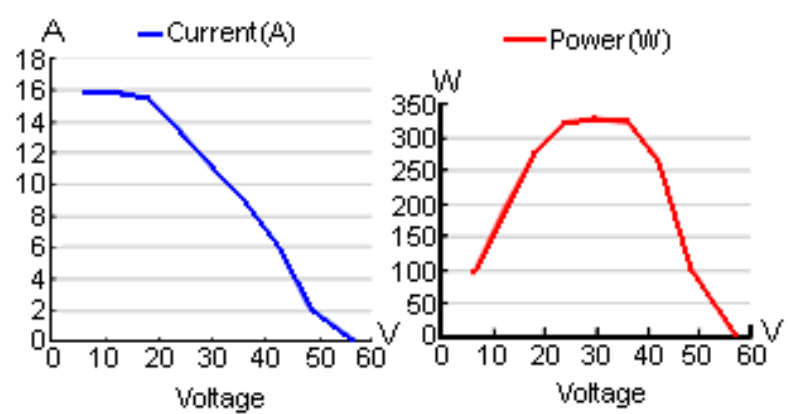

Fig. 3. Current-voltage and power characteristics of the 300W PEMFC

\section{B. UPS System}

In the PEMFC/battery hybrid UPS system, a boost active power factor corrector (PFC) with 160-275 VAC input voltage and fixed output voltage ( \pm 380 VDC) is analyzed and designed based on a high power factor preregular UC3854, which can make the input power factor (PF) of the AC/DC boost PWM rectifier be close to 1 , restrict the input current's THD less than $5 \%$, adopt the average current control and constant frequency control, and allow the frequency band of its current amplifier to be wide. Fig. 4 shows the single-phase active PFC AC/DC rectifier and its working pattern. The UC3854 working frequency is $100 \mathrm{kHz}$.

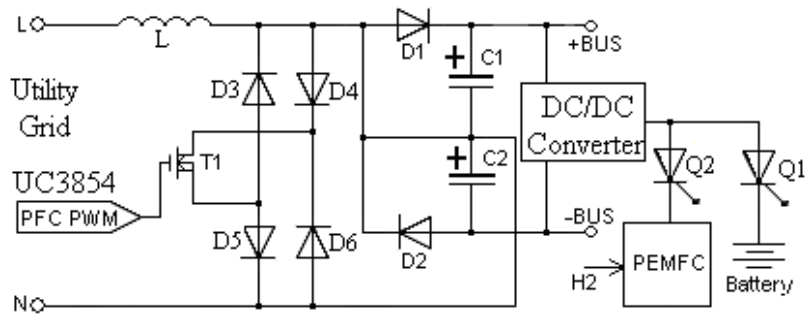

Fig. 4. Schematic diagram of an active PFC AC/DC rectifier with backup PEMFC/battery power supply

Using a TMS320F240 DSP, a DC/AC inverter has been designed to supply the load with a pure sine wave, as shown in Fig. 5, where the half-bridge inverter, LC filter and load are considered as the plant to be controlled. Since the switching frequency (the designed working frequency is $20 \mathrm{kHz}$ ) is much higher than the natural frequency and modulation frequency, the dynamics of the DC/AC inverter are mainly determined by its LC filter. Dead-time effect and inevitable loss in every part of the DC/AC inverter offer little damping. The damping effect can be considered as a small resistor connected in series with the filter inductor [6].

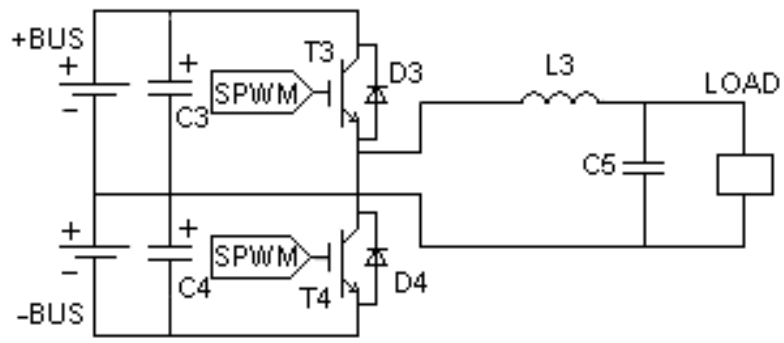

Fig. 5. Schematic diagram of the DC/AC inverter 
A basic switch power system with universal input and adjustable output voltage is designed as the charger of the battery based on a high performance current mode PWM controller UC3845. Fig. 6 shows the schematic circuit model of the AC/DC charger.

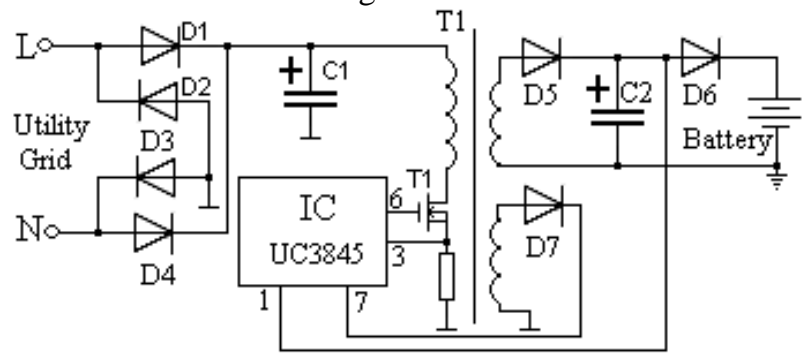

Fig. 6. Schematic diagram of AC/DC charger

A general and practical DC/DC converter for singlephase high frequency UPS is designed based on a regulating pulse width modulator UC3525. The PEMFC and battery are two kinds of low-voltage and high-current power source, so that their rated output voltage (36 VDC) should be boosted up to about \pm 380 VDC before the UPS inverter converts them into a $240 \mathrm{~V}, 50 \mathrm{~Hz}$ AC source. This boosting action is performed by DC/DC converters. Moreover, in the UPS system, energy storage units, such as a battery and super-capacitor, are required in the startup stage of PEMFC generator or during the external load sudden change. Fig. 7 illustrates the schematic model of the DC/DC converter. The operating frequency of the power switches $T_{1}$ and $T_{2}$ is $20 \mathrm{KHz}$.

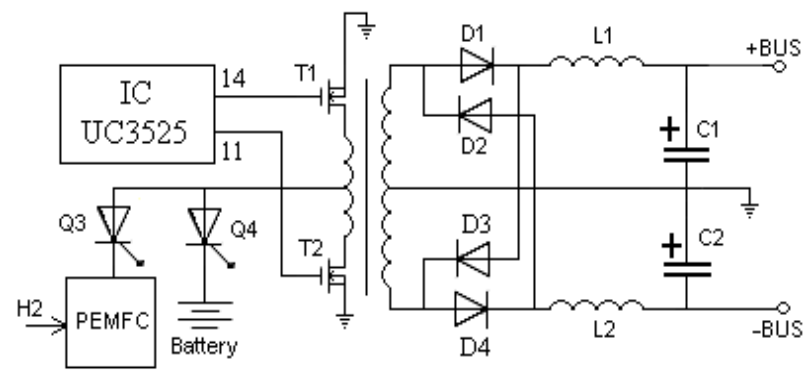

Fig. 7. Schematic diagram of DC/DC converter

\section{Batteries}

Generally speaking, in the hybrid PEMFC/battery UPS system, the PEMFC plays the role of main power supply under normal conditions and the battery provides the rest of the power when overload happens or when the PEMFC starts up. To realize this, the PEMFC needs a higher electrical potential than the battery. The battery type is LC-R127R2CH (PANASONIC ${ }^{\mathrm{TM}}$ ) with specifications of $12 \mathrm{~V}$ and 7.2 Ah.

\section{PEMFC/BATTERY HYBRID EXPERIMENT}

In the PEMFC/battery hybrid UPS system, when the utility grid power source is interrupted, the hydrogen will be supplied to the PEMFC stack that will supply the UPS system as the backup power source. The UPS system should ensure that there is enough fuel and battery capacity for providing the power needed by the external load. When the external load has a sudden change, however, the hydrogen cannot be fed fast enough to the PEMFC stack. Therefore, the UPS system also uses the battery to protect the PEMFC from excessive use and to feed power smoothly to the external load. The PEMFC/battery hybrid power source in parallel structure is employed.

For theoretical analysis and experimental study, a passive connection diagram is designed, similar to the actual one, by implementing a device to connect the PEMFC and battery [7, 8], as shown in Fig. 8. In the experiment setup, it is examined and found out that the passive electronic circuits can work well for the UPS load.

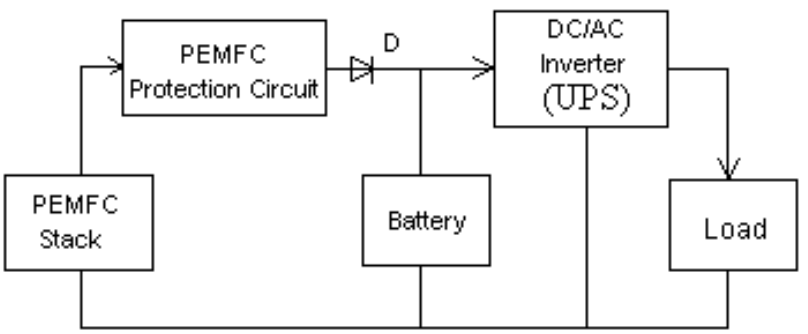

Fig. 8. Schematic diagram of connection between PEMFC and battery

In the PEMFC/battery hybrid UPS system used for the experiment, the PEMFC has series connection with its protection circuit, and parallel connection with the battery. The PEMFC in the UPS system is configured to output a constant power at all times, except when the load of the UPS has a sudden rise. The hybrid PEMFC/battery power source can also work when the external load exceeds the maximum power output of the PEMFC stack. In other words, the PEMFC/battery hybrid UPS system can supply power using the supplementary power stored in the battery. As revealed in Fig. 9, although the load suddenly changes from $60 \mathrm{~W}$ to $210 \mathrm{~W}$, the UPS can meet the power output requirement. After the transient process, the PEMFC stack would gradually increase its output to meet the load and the battery is cut off or at the recharging condition.

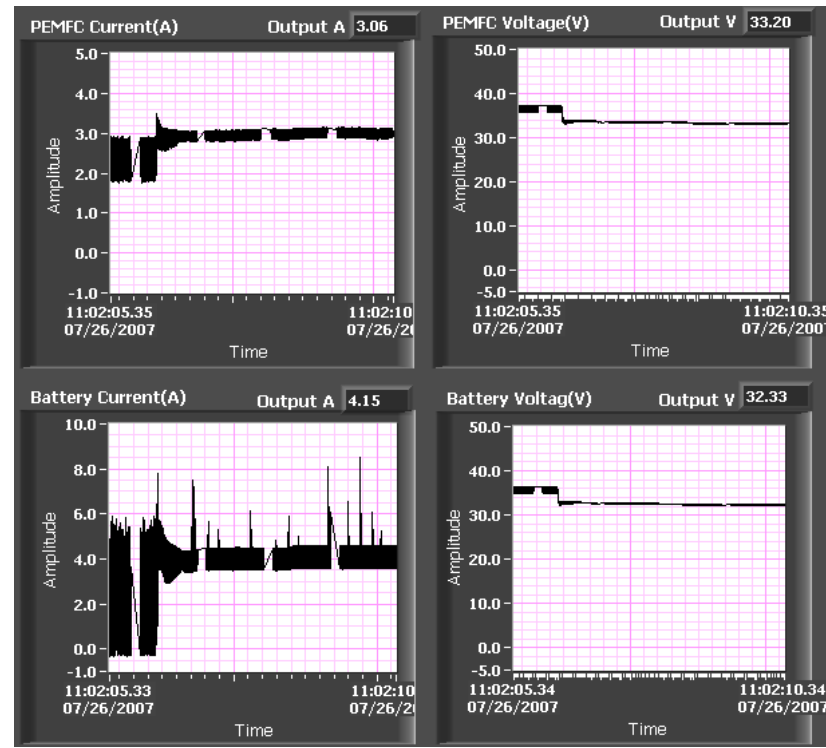

Fig. 9. Currents and voltages of the PEMFC and battery when the load of UPS changes from $60 \mathrm{~W}$ to $210 \mathrm{~W}$ 


\section{RESULTS AND DISCUSSIONS}

\section{A. Experimental Setup}

Fig. 10 shows the experimental setup of the proposed PEMFC and battery hybrid UPS for backup and emergency power applications. The experimental setup consists of an UPS system, PEMFC generating and test system, lead-acid batteries and a data-acquisition system (a multifunction I/O device NI6036E), an analog voltage output device NI6713, a parallel digital I/O interface PCI6503, and an analog multiplexer with temperature sensor AMUX-64T (National Instruments Australia Corporation). The UPS system with backup PEMFC and battery provides the AC power source to the linear loads (Lamp box) and nonlinear loads (PC computer), while the data-acquisition system measures and records the required information. In the PEMFC generating and test system, the hydrogen is regulated by mass flow controller (Type F-201C-GAS-22V, Bronkhorst). The temperature and humidity of hydrogen and air can be measured at the inlet by the hydro-transmitter (Type HD2008TV1, Delta OHM) as well as the pressure transmitter (Type AUS EX 1354X, Burkert) between the inlet of PEMFC stack. The output terminals of the UPS are connected to a lamp box and a PC computer that are used in constant voltage mode. All physical parameters like the currents and voltages of the UPS, the PEMFC stack and battery, the mass flow of the hydrogen, the pressure drop in the flow fields, the relative humidity and temperature of hydrogen are recorded with the data-acquisition system.

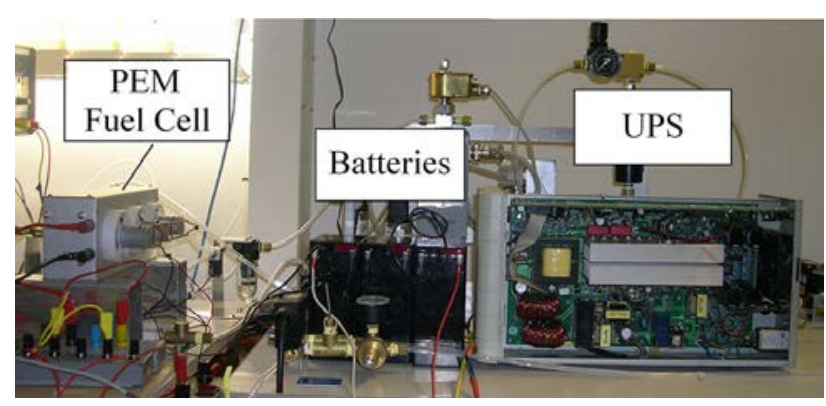

Fig. 10. Photo of experimental setup of the UPS with hybrid PEMFC and battery source

\section{B. Performance of the Hybrid PEMFC/Battery Source}

From Fig. 3, it can be seen that the voltage of the PEMFC decreases when the current increases. In other words, a load change causes a change in the output voltage. In the PEMFC/battery hybrid UPS system, during a load change or the startup of the PEMFC stack, the battery is needed as a supplementary power supply to keep the system voltage constant.

Fig. 11 shows the measured currents and powers of battery and PEMFC when the load changes. In the normal state, the load rise of the UPS keeps the current from the PEMFC higher than that from the battery over time. In other words, the PEMFC takes the majority of the load under normal conditions, and the battery provides the rest of the power.

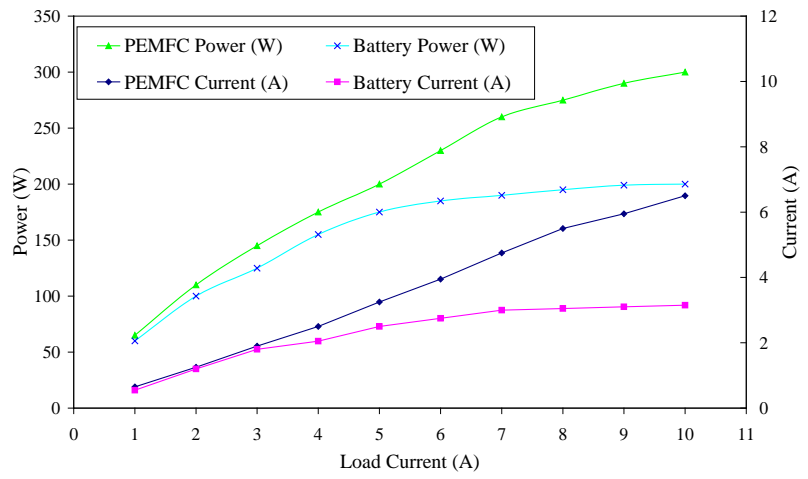

Fig. 11. Currents and powers of PEMFC and battery when the load current changes

\section{Performance of the UPS System}

The performances of the proposed hybrid UPS system are tested with the following specifications: input voltage of utility grid of 160-275 VAC, output voltage frequency of $50 \pm 5 \% \mathrm{~Hz}$, PEMFC/battery rated voltage of $36 \mathrm{VDC}$, and output power of $286 \mathrm{~W}$. The experimental load includes a DELL ${ }^{\mathrm{TM}}$ computer (Model: HP-U2106F3) with the maximum input power of $213 \mathrm{~W}$, and a monitor (Model: E772p) with a input power of 73W. Moreover, a lamp box is used as the supplementary load.

Figs. 12 and 13 illustrate the input voltage and output voltage of the UPS for utility grid input AC voltage failure and recovery. Both figures show that the uninterrupted output voltage has no overshoots and undershoots; confirming that a high quality output voltage of the designed UPS system with the PEMFC/battery hybrid power source is achieved. It can also be seen that very fast dynamic response has been achieved. Therefore, low sensitivity of output voltage against large load changes is obtained in the designed UPS system, as the good design concepts with the mature technology are included in the presented UPS system.

The performances of the designed UPS system with the PEMFC/battery hybrid power source are verified as follows: the output voltage of the UPS is $240 \pm 3 \%$ VAC, the output voltage frequency is $50 \pm 0.5 \% \mathrm{~Hz}$, the input power factor is larger than 0.95 , the output power factor is larger than 0.7 , the input current's THD is less than $5 \%$, and the transfer time is zero.

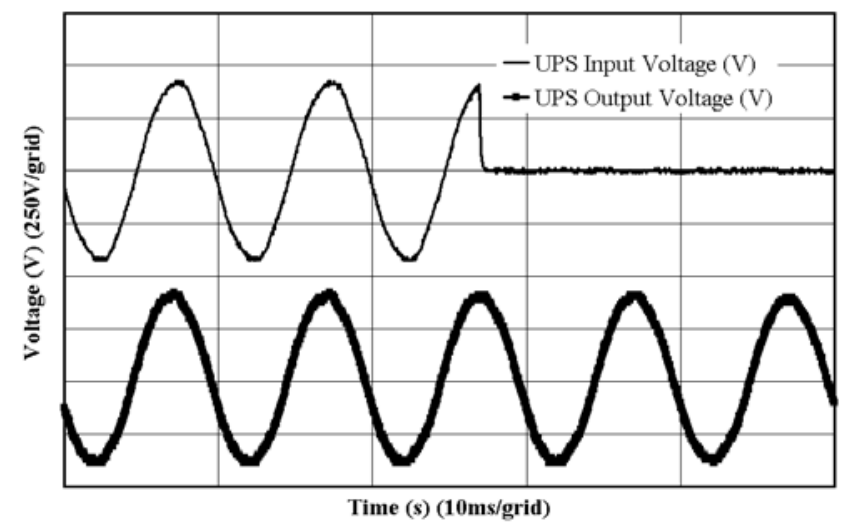

Fig. 12. Transitional waveform while the AC line is interrupted 


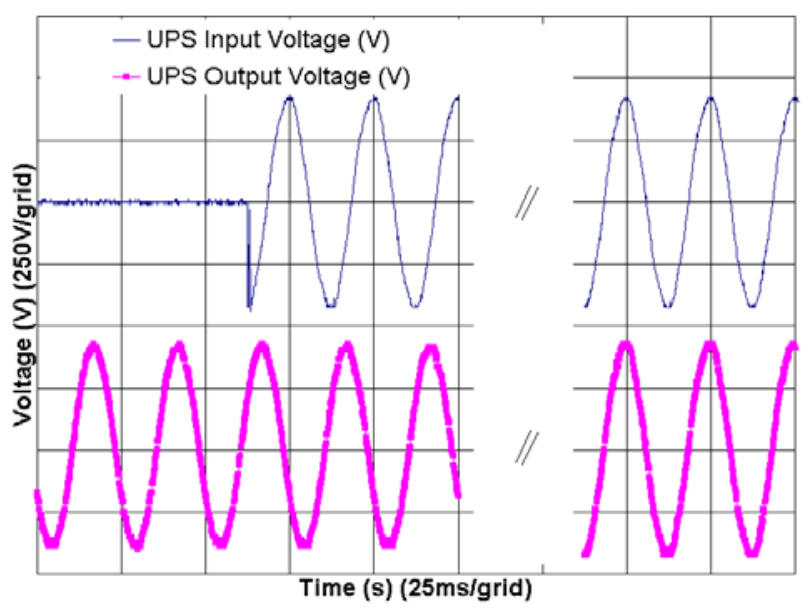

Fig. 13. Transitional waveform while the AC line recovers from backup status to the normal

\section{CONCLUSIONS}

A PEMFC/battery hybrid UPS system has been developed for backup and emergency power applications, which is mainly composed of a 36V/300W PEMFC stack, 3 cells 12V/7.2Ah lead-acid battery, and a UPS system, including an active $\mathrm{PFC} \mathrm{AC} / \mathrm{DC}$ rectifier, AC/DC charger, DC/AC inverter, DC/DC converter to boost 36VDC to \pm 380VDC, and their data-acquisition and control devices. The performance tests on both the PEMFC/battery hybrid power source and the UPS system have been conducted at the normal conditions. The hybrid UPS system has been applied to a computer to evaluate the operation ability as the AC power source. When the UPS system supplies the rated current for the computer, the PEMFC plays the role of main power source taking the majority of the load under normal operating conditions, and the battery provides the rest of the power when the AC line is interrupted. Although this PEMFC/battery hybrid UPS system still requires improvements for the practical use and the product development in backup and emergency power applications, this study has demonstrated its potential as the next-generation backup power unit for electronic devices.

\section{REFERENCES}

[1] S. B. Bekiarov and A. Emadi, "Unintermptible power supplies: classification, operation, dynamics and control," in Proc. IEEE Applied Power Electronics Conf. and Exposition, Dallas, Texas, USA, 2002, pp. 597-604.

[2] K. Fok, "Metal hydride fuel cells: a new and practical approach for backup and emergency power applications," in Proc. $28^{\text {th }}$ Int. Telecom. Energy Conf., Rhode Island, USA, 2006, pp. 1-6.

[3] K. Tüber, M. Zobel, H. Schmidt, and C. Hebling, “A polymer electrolyte membrane fuel cell system for powering backup computers,” Journal of Power Sources, vol. 122, pp. 1-8, 2003.

[4] J. S. Han and E. S. Park, "Direct methanol fuel-cell combined with a small backup battery," Journal of Power Sources vol. 112, pp. 477-483, 2002.

[5] Horizon Technology, "300W fuel cell stack operating instruments,” available at www.horizonfuelcell.com.

[6] B. Liu, S. Duan, Y. Kang, and J. Chen, "Genetic algorithm optimized fuzzy repetitive controller for low cost UPS inverter application," in Proc. IEEE Int. Conf. on Electrical Machines and Drives, 2005, pp. 840-845.

[7] B. D. Lee, D. H. Jung, and Y. H. Ko, “Analysis of DMFC/battery hybrid power system for backup applications,” Journal of Power Sources, vol. 131, pp. 207212, 2004.

[8] L. Gao, Z. H. Jiang, and R. A. Dougal, “An actively controlled fuel cell/battery hybrid to meet pulsed power demands," Journal of Power Sources, vol. 130, pp. 202207, 2004.

[9] B. J. Holland and J. G. Zhu, "Design of a 500W PEM fuel cell test system," in Proc. Australasian Universities Power Engineering Conf., Melbourne, Australia, Sept. 29 - Oct. 2, 2002.

[10] Y. D. Zhan, J. G. Zhu, Y. G. Guo, and A. Rodriguez, “An intelligent controller for PEM fuel cell power system based on double closed-loop control," in Proc. Australasian Universities Power Engineering Conf., Hobart, Australia, Sept. 25-28, 2005, pp. 174-179.

[11] Y. D. Zhan, J. G. Zhu, and Y. G. Guo, "Development of advanced hardware and software of proton exchange membrane fuel cell test systems," accepted for publication in Australian Journal of Electrical \& Electronic Engineering, in press. 